\title{
Acolhimento e Inclusão Social: Relato de Experiência de um Hospital Universitário Federal no Rio de Janeiro em Parceria com o Tribunal de Justiça
}

\author{
Pereira, Aída Mirian Miranda; Buarque, Maria da Conceição L.; \\ Rangel, Rosinea Alves \\ Hospital Universitário Clementino Fraga Filho/UFRJ — aida@hucff.ufrj.br
}

\begin{abstract}
I. INTRODUÇÃO: Este relato tem o propósito de apresentar reflexões e ações direcionadas à construção de concepção ampliada em relação ao acolhimento que é uma diretriz da Política Nacional de Humanização, através de parceria do Hospital Universitário Federal e o Tribunal de Justiça do Estado do Rio de Janeiro através dos Juizados Especiais Criminais (JECrim's), objetivando o recebimento do cidadão para cumprimento de pena de prestação de serviço ou pena pecuniária, utilizando-se o termo apenado para denominá-lo. Entendemos o acolhimento como processo ampliado, que se inicia com a entrada do cidadão em nossa instituição, permeando a utilização dos serviços e consideramos que é papel da universidade colaborar com esse projeto do Tribunal da Justiça que dá ênfase à conotação sócio-educativa propiciando a reflexão e convivência democrática. II. OBJETIVOS: a descentralização da execução das penas/medidas produzidas pelos JECrim's visa reduzir ao mínimo o tempo decorrido entre o cometimento do delito e o cumprimento da pena determinada pelo juiz. a possibilidade de conversão das penas de supressão de liberdade em penas restritivas de direitos - denominadas penas alternativas - pressupõe a parceria através de convênios firmados entre os Tribunais de Justiça e instituições, governamentais ou não, que prestem serviços de relevância social. III. METODOLOGIA: a efetivação da parceria se dá através da Comissão de Direitos do Paciente (CDP).No que se refere ao beneficiário (Hospital) há duas maneiras para receber o apenado: através de Prestação de Serviços ou da Pena Pecuniária, onde, neste caso, após serem recebidos e acolhidos recebem uma listagem para compra de equipamentos e materiais de consumo, conforme o valor estipulado pelo juiz responsável pelo caso. IV. RESULTADOS:. o convênio celebrado desde 2008 contemplou as solicitações de materiais dos diversos setores do hospital de modo imparcial, visto que as aquisições colaboraram de modo direto ou indireto com a prestação de uma assistência de qualidade ao paciente. o total de apenados recebidos foi de 183, sendo 109 para prestação de serviços e 74 para pagamento de pena pecuniária, totalizando até a presente data em $\mathrm{R} \$ 39.500,00$ (trinta e nove mil e quinhentos reais) aproximadamente. IV. CONCLUSÃO: Esta parceria contribuiu para o fortalecimento da noção de cidadania na instituição, ao mesmo tempo em que oferece um valioso efetivo de recursos humanos que colabora significativamente para melhorar os serviços prestados aos usuários. com relação aos apenados, verifica-se, em boa parte deles, que a interação no ambiente hospitalar é responsável por um crescimento pessoal e no campo dos valores. Além disso, proporciona uma importante fonte de doações para o hospital, o que contribui para garantir a qualidade dos serviços prestados em nossa instituição. V. BIBLIOGRAFIA: ACOLHIMENTO nas PRÁTICAS de PRODUÇÃO de SAÚDE - Ministério da Saúde - 2010;CONSTITUIÇÃO da REPÜBLICA FEDERATIVA do BRASIL .1988;RESSOCIALIZAÇÃO CONCRETA do PRESO. Projeto de pesquisa postado no site: http://investindonaeducacao.blogspot.com/.;TJ-RJ. JUDICIÁRIO do RIO de JANEIRO. Centrais de Penas e Medidas Alternativas.
\end{abstract}

Pereira, Aída Mirian Miranda; Buarque, Maria da Conceição L.; Rangel, Rosinea Alves. Acolhimento e Inclusão Social: Relato de Experiência de um Hospital Universitário Federal no Rio de Janeiro em Parceria com o Tribunal de Justiça. In: Anais do Congresso Internacional de Humanidades \& Humanização em Saúde [= Blucher Medical Proceedings, num.2, vol.1]. São Paulo: Editora Blucher, 2014. ISSN 2357-7282

DOI 10.5151/medpro-cihhs-10504 